\title{
Kelola
}

Jurnal Manajemen Pendidikan

\section{Dampak Biaya Kuliah Tunggal Terhadap Kualitas Layanan Pendidikan}

\author{
Sumarno \\ Pendidikan Ekonomi, FKIP, Universitas Riau \\ sumarno.s@lecturer.unri.ac.id \\ Gimin \\ Pendidikan Ekonomi, FKIP, Universitas Riau \\ gim_unri@yahoo.co.id \\ Syakdanur Nas \\ Pendidikan Ekonomi, FKIP, Universitas Riau \\ danunas@yahoo.co.id
}

\begin{abstract}
This study aims to determine the differences in the number of single tuition fees and non-single tuition; the proportion of resources and the allocation of funds before and after the single tuition policy; and the quality of educational services by single tuition and non-single tuition college students. The data was collected from students and leaders at the University of Riau through questionnaires, documentation, and interviews. Data were analyzed descriptively and different test. The results show that the amount of a single tuition fee is not much different from the non-single tuition fee. The proportion of funding sources from the public increased after a single tuition policy, but the proportion of allocations for operational costs decreased. Single tuition college students rated the quality of educational services lower than the non-single tuition of students with significant differences. Single tuition does not significantly affect the quality of education services.
\end{abstract}

Keywords: single tuition fee, education services

\section{Article Info}


PENDAHULUAN

Uang Kuliah Tunggal menurut Peraturan Menteri Pendidikan dan Kebudayaan (Permendikbud) No. 55 Tahun 2013 antara lain dimaksudkan untuk meringankan beban mahasiswa terhadap pembiayaan pendidikan. Dalam pasal 5 disebutkan bahwa perguruan tinggi negeri tidak boleh memungut uang pangkal dan pungutan lain selain uang kuliah tunggal dari mahasiswa baru program sarjana (S1) dan program diploma mulai tahun akademik 2013/2014.

Kebijakan Permendikbud tentang uang kuliah tunggal (UKT) dimaksudkan untuk meringankan beban mahasiswa, namun dalam pelaksanaannya menuai banyak kritikan dan penolakan karena justru dianggap memberatkan mahasiswa. Kritikan dan penolakan terhadap kebijakan UKT tersebut juga muncul dari mahasiswa Universitas Riau. Sebagaimana diberitakan di berbagai media (riaupos.co, $26 \quad$ Mei 2013; bahanamahasiswa.co, 10 Juni 2013; kampus.okezone.com, 08 Oktober 2013; pewarta-indonesia.com, 09 Oktober 2013; gagasanriau.com, 05 Desember 2013) yang intinya mahasiswa keberatan dan menolak kebijakan UKT karena terlalu mahal, memberatkan, dan tidak transparan.

Menurut PP No.17 Tahun 2010 tentang Pengelolaan dan Penyelenggaraan Pendidikan, Bab II Pasal 3 ayat b, pengelolaan pendidikan ditujukan untuk menjamin mutu dan daya saing pendidikan serta relevansinya dengan kebutuhan dan/atau kondisi masyarakat. Karena pengelolaan pendidikan ditujukan untuk menjamin mutu maka pembiayaan pendidikan dimaksudkan untuk meningkatkan mutu pendidikan, sebagaimana pendapat Wissema (2009) bahwa salah satu faktor intrinsik yang berpengaruh besar terhadap peningkatan mutu pendidikan di perguruan tinggi adalah ketersediaan dana. Begitu juga hasil penelitian Moses \& Rahmayanti (2008) tentang Faktor-Faktor Yang Mempengaruhi Kualitas Pendidikan Pada Perguruan Tinggi menyimpulkan bahwa faktor keuangan berpengaruh secara signifikan terhadap kualitas pendidikan. Dalam UU No. 12 Tahun 2012 tentang Pendidikan Tinggi pasal 83 (1) disebutkan bahwa Pemerintah menyediakan dana Pendidikan Tinggi yang dialokasikan dalam Anggaran Pendapatan dan Belanja Negara (APBN). Di samping dana dari APBN, pendanaan pendidikan tinggi juga dapat bersumber dari pemerintah daerah, masyarakat, maupun biaya yang ditanggung mahasiswa sesuai dengan kemampuan mahasiswa, orang tua mahasiswa, atau pihak lain yang membiayainya.

Mulyasa (2004) mengungkapkan bahwa komponen keuangan dan pembiayaan merupakan komponen yang menentukan terlaksananya kegiatan proses belajar mengajar yang penggunaannya antara lain untuk biaya fasilitas dan alat-alat pengajaran (barang habis pakai). Begitu juga Michael (2005) yang menyatakan bahwa pengurangan pendanaan menyebabkan kondisi layanan yang memburuk, pemeliharaan bangunan yang terbengkalai, dan penurunan kualitas akademis. Pernyataan tersebut juga sesuai pendapat Sumarno (2012) yang mengungkapkan bahwa rendahnya mutu Perguruan Tinggi (PT) di Indonesia salah satunya disebabkan oleh rendahnya dana untuk membiayai PT. Pengaruh pendanaan terhadap mutu pendidikan juga dibuktikan oleh data yang terungkap dalam penelitiannya Sumarno, Kartikowati, \& Astuti (2014) bahwa besarnya uang komite yang ditanggung siswa pada sekolah unggul besarnya tiga kali lipat daripada uang komite sekolah biasa. Hal itu menunjukkan bahwa bila dana pendidikannya kecil, maka mutunya terbatas atau menjadi rendah.

Proporsi sumber dana masyarakat (termasuk didalamnya uang kuliah dari mahasiswa) setelah penerapan UKT mengalami kenaikan, yaitu menjadi sebesar 75,8\% sedangkan sebelumnya hanya $67,4 \%$. Proporsi alokasi dananya juga ada yang mengalami kenaikan yaitu alokasi untuk belanja barang yaitu menjadi sebesar $52,4 \%$ dari sebelumnya 48,7\%; sedangkan alokasi untuk belanja modal menurun yaitu menjadi $13,1 \%$ dari sebelumnya sebesar $14,7 \%$. Adanya kenaikan sumber dana 
Kelola: Jurnal Manajemen Pendidikan, Vol. 4, No. 2, Juli-Desember 2017

masyarakat dan alokasinya untuk belanja barang, secara teoretik akan menaikan mutu layanan pendidikannya.

Menurut Ruben (1999), ada lima hal pokok yang harus diperhatikan oleh manajemen perguruan tinggi agar terjaga mutu pendidikannya, yaitu: 1) teaching/ learning; 2) service/ outreach; 3) schollarship/ research;4) workplace satisfaction, dan 5) financial. Lebih lengkap (Ruben, Schreiner dan Juillerat, 2009) dalam mengukur layanan pendidikan menggunakan Student Satisfaction Inventory yang meliputi 9 aspek, yaitu: 1) academic advising effectiveness, 2) campus climate, 3) campus life, 4) campus support services, 5) instructional effectiveness, 6) recruitment and financial aid effectiveness, 7) registration effectiveness, 8) safety and security, and 9) student centeredness.

Mengacu pada permasalahan dan pemikiran di muka, penelitian ini mengkaji tentang UKT dan pengaruhnya terhadap layanan pendidikan. Tujuan penelitian ini untuk mengetahui: a) Ada tidaknya perbedaan besaran UKT dan uang kuliah sebelum kebijakan UKT diterapkan, b) Proporsi sumber dan alokasi dana pendidikan sebelum dan sesudah penerapan UKT, c) Mutu layanan pendidikan yang dirasakan mahasiswa UKT dan non-UKT.

\section{METODE PENELITIAN}

Penelitian ini merupakan penelitian deskriptif yang mencoba mengungkap tentang penerapan UKT dan pengaruhnya terhadap mutu layanan pendidikan yang dirasakan mahasiswa. Penelitian dilakukan di Universitas Riau, dengan respondennya adalah unsur pimpinan dan mahasiswa di lingkungan Universitas Riau. Responden pimpinan di lingkungan Universitas diambil dengan teknik purposive sampling, yaitu para pimpinan, baik di tingkat universitas maupun fakultas, yang memahami tentang kebijakan keuangan UKT/ non-UKT dan pengelolaan keuangannya. Responden mahasiswa diambil dengan teknik cluster random sampling, yaitu kelompok mahasiswa UKT (angkatan 2013/2014) dan kelompok mahasiswa non-UKT (angkatan sebelum 2013). Masing-masing kelompok UKT dan non-UKT tersebut diambil secara acak di sembilan fakultas, dengan jumlah mahasiswa 30 orang setiap fakutas (15 orang mahasiswa UKT dan 15 orang mahasiswa nonUKT) sehingga jumlah sampel mahasiswa sebanyak 270 orang (135 mahasiswa UKT dan 135 mahasiswa non-UKT). Data penelitian dikumpulkan dengan teknik pemberian angket, dokumentasi, dan wawancara. Angket digunakan untuk mengumpulkan data tentang mutu layanan pendidikan dan biaya pendidikan yang dikeluarkan oleh mahasiswa nonUKT. Instrumen angket tentang mutu layanan pendidikan merupakan angket tertutup yang disusun berdasarkan konsep mutu layanan pendidikan sembilan indikator dengan skala penilaian 1 hingga 5 (Tidak Memuaskan hingga Sangat Memuaskan). Instrumen angket tentang biaya penndidikan mahasiswa non-UKT merupakan angket terbuka yang disusun berdasarkan konsep biaya pendidikan yang dikeluarkan mahasiswa untuk keperluan kuliahnya, selain biaya pribadi. Dokumentasi untuk mengumpulkan data tentang pembiayaan pendidikan yang dikelola oleh universitas, baik yang bersumber dari mahasiswa maupun dari sumber lainnya.

Data dianalisis secara deskriptif dan uji beda. Analisis deskriptif untuk mendapatkan gambaran tentang: biaya kuliah baik yang UKT maupun non-UKT, mutu layanan pendidikan yang diterima mahasiswa, serta proporsi sumber dan alokasi dana pendidikan Universitas Riau. Analisis uji beda dengan teknik uji t beda rata-rata, untuk menganalisis ada tidaknya perbedaan besarnya biaya kuliah UKT dan non-UKT serta perbedaan layanan pendidikan yang diterima mahasiswa UKT dan non-UKT.

\section{HASIL DAN PEMBAHASAN Hasil Penelitian}

Pada hasil penelitian ini akan dipaparkan mengenai biaya pendidikan oleh mahasiswa UKT dan non-UKT serta perbedaannya; proporsi sumber dan alokasi dana pendidikan universitas; serta layanan pendidikan yang 
Dampak Biaya Kuliah Tunggal Terhadap Kualitas Layanan Pendidikan | Sumarno, dkk.

diterima oleh mahasiswa UKT dan non-UKT beserta perbedaannya.

\section{Biaya pendidikan mahasiswa UKT dan Non- UKT}

Data biaya pendidikan yang dikeluarkan oleh mahasiswa UKT mapun non-UKT di Universitas Riau dapat ditunjukkan pada tabel 1 berikut.

Tabel 1. Data Biaya Pendidikan Mahasiswa Kelompok UKT dan Non-UKT

\begin{tabular}{lrr}
\hline \multicolumn{1}{c}{ Indeks } & \multicolumn{1}{c}{$\begin{array}{c}\text { Mhs UKT } \\
(\mathrm{Rp})\end{array}$} & $\begin{array}{c}\text { Mhs Non-UKT } \\
(\mathrm{Rp})\end{array}$ \\
\hline Minimum & $500.000,00$ & $750.000,00$ \\
Maksimum & $13.425 .000,00$ & $27.000 .000,00$ \\
Rata-rata & $3.749 .614,81$ & $3.578 .950,77$ \\
Mode & $3.125 .000,00$ & $904.200,00$ \\
\hline
\end{tabular}

Sumber: data penelitian, diolah

Tabel 1. di atas menunjukkan bahwa ratarata dan mode biaya pendidikan yang dikeluarkan kelompok mahasiswa UKT di Universitas Riau lebih tinggi dibanding kelompok non-UKT. Nilai rata-rata yang lebih tinggi (Rp3.749.614,81 dibanding Rp3.578.950,77) menggambarkan bahwa penerapan kebijakan UKT di Universitas Riau secara umum meningkatkan jumlah absolut biaya pendidikan yang harus ditanggung/dikeluarkan mahasiswa. Begitu juga nilai mode yang lebih tinggi Rp3.125.000,00 dibanding Rp904.200,00), menggambarkan bahwa mahasiswa kelompok UKT yang membayar biaya pendidikan lebih tinggi jumlahnya lebih banyak dibandingkan mahasiswa kelompok non-UKT. Hanya saja rentang jumlah biaya pendidikan mahasiswa kelompok UKT (minimum Rp500.000,00 maksimum Rp13.425.000,00) lebih rendah disbandingkan mahasiswa kelompok non-UKT (minimum Rp750.000,00 maksimum Rp27.000.000,00). Artinya bahwa pada mahasiswa kelompok UKT hanya menanggung biaya pendidikan antara Rp500.000,00 hingga Rp13.425.000,00; sedangkan mahasiswa kelompok non-UKT tanggungan biaya pendidikannya antara Rp750.000,00 hingga Rp27.000.000,00. Rentang besaran uang kuliah mahasiswa non-UKT yang lebih besar tersebut dapat menggambarkan bahwa masyarakat/ mahasiswa memiliki kemampuan ekonomi untuk menanggung biaya kuliah yang lebih tinggi dari besaran UKT (Rp500.000,00 hingga Rp13.425.000,00).

Walaupun secara absolut ada perbedaan rata-rata biaya pendidikan antara mahasiswa kelompok UKT dan Non UKT, namun secara statistik ternyata tidak ada perbedaan yang signifikan, sebagaimana ditunjukkan oleh hasil uji beda seperti tabel 2 berikut.

Tabel 2. Hasil Uji Beda Biaya Pendidikan Mahasiswa Kelompok UKT dan Non-UKT

\begin{tabular}{llllllll}
\hline & & \multicolumn{2}{c}{$\begin{array}{c}\text { Uji } \\
\text { Perbedaan } \\
\text { Varians }\end{array}$} & & \multicolumn{3}{c}{$\begin{array}{c}\text { Uji Perbedaan Rata- } \\
\text { rata }\end{array}$} \\
\cline { 3 - 7 } & F & Sig. & t & df & Sig. \\
\hline Biaya Varians sama & 8.020 & .005 & .348 & 268 & .728 \\
$\begin{array}{l}\text { Pendi- Varians tidak } \\
\text { dikan }\end{array}$ & & & .348 & 217.650 & .728 \\
\hline
\end{tabular}

Sumber: Hasil pengolahan data

Tabel 2. di atas menunjukan thitung 0,348 dengan probabilitas $0,728>0,05$. Itu berarti bahwa rata-rata biaya pendidikan dari kedua kelompok sampel tersebut tidak ada perbedaan yang signifikan. Tidak adanya perbedaan secara statistik antara biaya pendidikan mahasiswa UKT dan non-UKT memberikan gambaran bahwa besaran biaya pendidikan diantara kedua kelompok mahasiswa tersebut secara umum tidak berbeda secara signifikan. Hal ini dapat diartikan bahwa secara keseluruhan besaran biaya pendidikan UKT dan non-UKT relatif sama. Hal tersebut mengandung makna bahwa biaya pendidikan mahasiswa non-UKT yang dikeluarkan sepanjang semester hampir (relatif) sama dengan biaya kuliah mahasiswa UKT yang dikeluarkan (dibayar) sekaligus pada saat membayar uang kuliah pada awal semester. Pengeluaran yang hanya sekaligus tersebut yang kemungkinan menjadi keberatan mahasiswa, karena harus ada dana sejumlah kelompok UKT-nya pada saat membayar uang kuliah (SPP).

Proporsi sumber dan alokasi dana pendidikan di universitas

Penerimaan Universitas Riau (UR) tahun 2013 (sebelum UKT) sebesar 
Kelola: Jurnal Manajemen Pendidikan, Vol. 4, No. 2, Juli-Desember 2017

Rp394.166.849.000,00 sedangkan tahun 2014 (sesudah UKT) sebesar Rp413.728.568.000,00. Jumlah absolut tersebut menunjukkan bahwa dana pendidikan sesudah kebijakan UKT lebih besar dibandingkan sebelum kebijakan UKT. Hal itu sesuai dengan hasil uji deskriptif biaya pendidikan mahasiswa, bahwa dengan adanya penerapan kebijakan UKT dana pendidikan yang diterima universitas meningkat karena rata-rata dan jumlah mahasiswa yang membayar biaya pendidikan lebih besar setelah penerpan kebijakan UKT.

Dana tersebut digunakan untuk membiayai berbagai kegiatan baik untuk untuk kegiatan fakultas maupun lembaga-lembaga pendukung lainnya, baik untuk investasi maupun biaya operasional. Sumber penerimaan dua tahun terakhir (2013 dan 2014) sebagian besar berasal dari dana masyarakat sebesar $67,4 \%$ dan 75,8\% yang berupa PNBP (Penerimaan Negara Bukan Pajak) sebesar $100 \%$ dan $99,9 \%$. Sumber lainnya yaitu dari Pemerintah sebesar $32,6 \%$ dan $24,2 \%$ yang berupa BOPTN (Biaya Operasional Perguruan Tinggi Negeri) sebesar $100 \%$ dan $85,1 \%$. Meskipun pada tahun 2014 ada sumber dari kegiatan usaha tetapi proporsinya sangat kecil yaitu hanya $0,1 \%$. Besarnya peningkatan sumber dana dari dana masyarakat pada tahun 2014 (dari 67,4\% menjadi 75,8\%) yang melebihi dari peningkatan sumber kegiatan usaha (dari $0 \%$ menjadi $0,1 \%$ ) menunjukkan bahwa sumber dana dari uang kuliah mahasiswa (PNBP) pada tahun 2014 (setelah penerapan UKT) meningkat.

Dilihat dari penggunaanya, dana tersebut sebagian besar teralokasi untuk membiayai "Belanja Pegawai" dan "Belanja Barang", yaitu pada tahun 2013 masing-masing 34,5\% dan 52,4\%; sedangkan tahun 2014 masing-masing $34,4 \%$ dan $48,7 \%$. Penggunaan dana untuk belanja modal relatif kecil (13,1\% dan 14,7\%), begitu juga untuk bantuan sosial $(0,00 \%$ dan $2,2 \%$ ). Proporsi belanja pegawai pada tahun 2014 (sesudah penerapan UKT) dan pada tahun 2013 (sebelum penerapan UKT) ternyata relatif sama yaitu masing-masing sebesar $34,4 \%$ dan $34,5 \%$, sedangkan proporsi belanja barang (operasional non gaji/ tunjangan) pada tahun 2014 (sesudah penerapan UKT) ternyata lebih kecil dibanding pada tahun 2013 (sebelum penerapan UKT), yaitu menjadi $48,7 \%$ dari sebelumnnya sebesar $52,4 \%$. Hal itu dapat menunjukkan bahwa biaya untuk kegiatan operasional setelah penerapan UKT (tahun 2014) menurun dibanding sebelum penerapan UKT (tahun 2013). Proporsi sumber dan penggunaan dana beserta unsur masingmasingnya dapat ditunjukkan seperti pada tabel 3 berikut.

Tabel 3. Proporsi Sumber dan Penggunaan Dana Universitas Riau Tahun 2013 dan 2014

\begin{tabular}{|c|c|c|}
\hline Sumber Dana & Tahun & Proporsi \\
\hline \multirow{2}{*}{ 1. Pemerintah: } & 2013 (non UKT) & $32,6 \%$ \\
\hline & 2014 (UKT) & $24,2 \%$ \\
\hline \multirow{3}{*}{$\begin{array}{l}\text { a. Bantuan } \\
\text { Operasional } \\
\text { Perguruan Tinggi } \\
\text { Negeri (BOPTN) }\end{array}$} & 2013 & $100,0 \%$ \\
\hline & 2014 & \\
\hline & & $85,1 \%$ \\
\hline \multirow[b]{2}{*}{ b. Hibah } & 2013 & $0,0 \%$ \\
\hline & 2014 & $14,9 \%$ \\
\hline \multirow{2}{*}{ 2. Masyarakat: } & 2013 (non UKT) & $67,4 \%$ \\
\hline & 2014 (UKT) & $\mathbf{7 5 , 8 \%}$ \\
\hline \multirow{2}{*}{$\begin{array}{l}\text { a. Penerimaan Negara } \\
\text { Bukan Pajak (PNBP) }\end{array}$} & 2013 & $100,0 \%$ \\
\hline & 2014 & $99,9 \%$ \\
\hline \multirow{2}{*}{ b. Kegiatan usaha } & 2013 & $0,0 \%$ \\
\hline & 2014 & $0,1 \%$ \\
\hline \multirow{2}{*}{ Penggunaan Dana } & 2013 (non UKT) & $100 \%$ \\
\hline & 2014 (UKT) & $100 \%$ \\
\hline \multirow{2}{*}{ 1. Belanja Pegawai } & 2013 & $34,5 \%$ \\
\hline & 2014 & $34,4 \%$ \\
\hline \multirow{2}{*}{ 2. Belanja Barang } & 2013 & $52,4 \%$ \\
\hline & 2014 & $48,7 \%$ \\
\hline \multirow{2}{*}{ 3. Belanja Modal } & 2013 & $13,1 \%$ \\
\hline & 2014 & $14,7 \%$ \\
\hline 4. Belanja Bantuan & 2013 & $0,0 \%$ \\
\hline Sosial & 2014 & $2,2 \%$ \\
\hline
\end{tabular}

Sumber: Bag. Keuangan UR, diolah.

\section{Mutu Layananan Pendidikan}

Menurut penilaian mahasiswa secara keseluruhan (mahasiswa UKT dan non-UKT), mutu layanan pendidikan di Universitas Riau secara umum sudah masuk kategori tinggi. Adapun sebarannya dapat ditunjukkan seperti dalam tabel berikut. 
Dampak Biaya Kuliah Tunggal Terhadap Kualitas Layanan Pendidikan | Sumarno, dkk.

Tabel 4. Mutu Layanan Pendidikan Universitas Riau Menurut Persepsi Mahasiswa

\begin{tabular}{lccc}
\hline \multicolumn{1}{c}{ Kategori } & Frekuensi & $\%$ & $\%$ Kumulatif \\
\hline Sangat Tinggi & 17 & 6.3 & 6.3 \\
Tinggi & 223 & 82.6 & 88.9 \\
Rendah & 23 & 8.5 & 97.4 \\
Sangat Rendah & 7 & 2.6 & 100.0 \\
Jumlah & 270 & 100.0 & \\
\hline
\end{tabular}

Sumber: Hasil Pengolahan data

Tabel 4. di atas menunjukan bahwa secara umum $(82,6 \%)$ mahasiswa responden menilai mutu layanan pendidikan Universitas Riau tergolong kategori tinggi, bahkan 6,3\% menyatakan sangat tinggi. Meskipun ada mahasiswa yang merasakan mutu layanan pendidikan Universitas Riau pada kategori rendah dan sangat rendah, namun relatif kecil yaitu sebesar $11,1 \%$. Bila dilihat dari masingmasing kelompok mahasiswa UKT dan nonUKT, mutu layanan pendidikannya nampak dalam tabel berikut.

Tabel 5. Skor Mutu Layanan Pendidikan Universitas Riau Berdasar Kelompok Uang Kuliah Mahasiswa

\begin{tabular}{llrrr}
\hline & Kelompok & n & Rata-rata & $\begin{array}{c}\text { Simpangan } \\
\text { baku }\end{array}$ \\
\hline Layanan & UKT & 135 & 2,973 & 0,5416 \\
Pendidikan & Non UKT & 135 & 3,209 & 0,4203 \\
\hline
\end{tabular}

Sumber: Hasil pengolahan data

Rata-rata Skor mutu layanan pendidikan pada Tabel 5. di atas nampak bahwa kelompok mahasiswa non-UKT lebih besar daripada kelompok mahasiswa UKT. Hal itu menunjukkan bahwa mahasiswa Non-UKT rata-rata memberikan penilaian mutu pelayanan yang lebih tinggi dibanding mahasiswa UKT $(3,209>2,973)$. Ini berarti bahwa layanan pendidikan yang dirasakan oleh mahasiswa UKT lebih rendah dibanding yang dirasakan oleh mahasiswa non-UKT. Perbedaan tersebut ternyata terbukti signifikan secara statistik, dimana nilai thitung sebesar -3.992 dengan signifikansinya sebesar $0,000<0,05$ ). Hal tersebut menggambarkan bahwa secara absolut dan relatif mahasiswa kelompok UKT merasakan layanan pendidikan yang lebih rendah dibandingkan layanan pendidikan yang dirasakan oleh mahasiswa kelompok non-UKT. Hasil uji beda statistik tentang mutu layanan dari kelompok mahasiswa UKT dan kelompok mahasiswa non-UKT tersebut dapat ditunjukkan pada tabel 6 .

Adanya perbedaan secara signifikan mutu layanan yang dirasakan oleh kedua kelompok mahasiswa tersebut dapat dikatakan bahwa penerapan UKT menurunkan mutu layanan yang dirasakan mahasiswanya. Kondisi tersebut dapat diduga disebabkan oleh adanya penurunan proporsi penggunaan dana untuk belanja barang (operasional non gaji/tunjangan) pada masa penerapan UKT. Tetapi dapat saja disebabkan mahasiswa kelompok UKT "merasa" membayar uang kuliah yang lebih besar sebagaimana terungkap pada rata-rata dan modus biaya pendidikan mahasiswa UKT yang lebih besar daripada mahasiswa non-UKT.

Tabel 6. Hasil Uji Beda Mutu Layanan Pendidikan Mahasiswa UKT dan Non-UKT

\begin{tabular}{llrrrrr}
\hline & & \multicolumn{2}{c}{ Uji Perbedaan } & & & \\
& & Uarians & & \\
& & F & Sig & t & df & Sig. \\
\cline { 3 - 7 } & & 2,195 & 0,140 & $-3,992$ & 268 & 0,000 \\
Layan & Varians & & & & \\
an & sama & & & & & \\
Pendi & Varians \\
dikan & & & & $-3,992$ & 252,440 & 0,000 \\
& $\begin{array}{l}\text { tidak } \\
\text { sama }\end{array}$ & & & & & \\
\hline
\end{tabular}

Sumber: hasil pengolahan data

\section{Pengelolaan UKT di Universitas Riau}

Besaran UKT di Universitas Riau dibagi dalam lima kategori yang didasarkan pada kelompok kemampuan ekonomi orangtua/mahasiswa. Kelompok 1 merupakan kategori uang kuliah per semester yang paling rendah yang diperuntukkan bagi orang tua/mahasiswa yang kemampuan ekonominya termasuk tidak mampu atau miskin. Kelompok 2 merupakan uang kuliah yang besarnya lebih tinggi daripada Kelompok 1 yang diperuntukkan bagi orangtua/mahasiswa yang kemampuan ekonominya lebih tinggi daripada Kelompok 1. Begitu seterusnya, peningkatan kelompoknya merupakan peningkatan besaran uang kuliahnya, hingga Kelompok 5 yang besarnya uang kuliahnya paling tinggi. 
Kelola: Jurnal Manajemen Pendidikan, Vol. 4, No. 2, Juli-Desember 2017

Sebaran proporsi jumlah mahasiswa UKT Kelompok 4 dan 5 pada tahun 2014 sebanyak $76 \%(15,5 \%+60,5 \%)$. Jumlah ini mengalami peningkatan $3,2 \%$ dari tahun sebelumnya yang jumlahnya $72,8 \%(14,8 \%+58 \%)$. Disisi lain, jumlah mahasiswa pada UKT Kelompok 1 pada tahun 2014 sebanyak 1,9\%. Jumlah ini mengalami penurunan sebesar 3,3\% dari tahun sebelumnya yang jumlahnya $5,2 \%$. Penurunan jumlah mahasiswa UKT Kelompok 1 pada tahun 2014 tersebut terjadi pada semua fakultas. Penurunan tersebut menyebabkan proporsi jumlah mahasiswa UKT Kelompok 1 pada tahun 1014 tidak memenuhi jumlah minimal (5\%) dari jumlah mahasiswa yang diterima, sesuai Permendikbud. Hal yang demikian dapat terjadi karena kekeliruan dalam pembagian proporsi jumlah mahasiswa dalam kelompok UKT; tetapi hal yang positifnya dapat menggambarkan bahwa kemampuan ekonomi orang tua/mahasiswa yang masuk kategori tidak/kurang mampu hanya sedikit, yaitu hanya $1,9 \%$ dari seluruh mahasiswa UKT.

\section{Pembahasan}

Dari hasil penelitian tentang biaya pendidikan atau uang kuliah mahasiswa seperti diungkapkan di muka, secara absolut nominal rata-rata uang kuliah mahasiswa kelompok UKT lebih besar, namun secara statistik menunjukkan tidak ada perbedaan yang signifikan. Artinya, besaran uang kuliah mahasiswa UKT dan mahasiswa non-UKT relatif tidak berbeda. Besaran rata-rata uang kuliah mahasiswa kelompok UKT yang lebih besar dapat dipandang bahwa masyarakat memiliki kemampuan yang lebih besar untuk membiayai pendidikan mereka di perguruan tinggi. Di sisi yang lain dapat juga dipandang bahwa masyarakat memiliki kesadaran untuk dapat mengalokasikan sumber daya keuangan rumah tangganya untuk kepentingan pendidikan anak yang lebih baik. Hal itu sesuai pendapat Elfindri (2011) bahwa anggaran pendidikan di Indonesia perlu memenuhi unsur rational choice untuk memenuhi pencapaian target pendidikan, pemerataan, dan kualitas, yang antara lain dengan mengajak masyarakat agar sadar dan mampu mengalokasikan sumber dayanya secara optimal untuk kepentingan kesejahteraan rumah tangga.

Walaupun secara relatif uang kuliah mahasiswa UKT tidak berbeda dengan mahasiswa non-UKT, tetapi karena pengeluaran uang kuliah mahasiswa UKT harus dibayarkan sekaligus pada awal semester, maka seolah-olah besarannya lebih besar secara signifikan. Karena dibayar sekaligus pada awal semester, mereka juga merasa bebannya menjadi berat. Hal demikian menyebabkan mahasiswa merasa bahwa penerapan kebijakan UKT menjadikan uang kuliahnya terlalu mahal dan memberatkan sebagaimana yang dilansir dalam media massa seperti: riaupos.co, $26 \mathrm{Mei}$ 2013; bahanamahasiswa.co, 10 Juni 2013; kampus. okezone.com, 08 Oktober 2013; pewarta-indonesia.com, 09 Oktober 2013; gagasanriau.com, 05 Desember 2013. Kondisi mahasiswa UKT yang merasa bahwa UKT menjadi mahal dan memberatkan tentu menjadi dilema bagi universitas karena untuk menyelenggarakan pendidikan yang bermutu, perguruan tinggi memerlukan biaya besar dan mahal (Indrawan, 2008). Terhadap masalah ini universitas perlu melakukan pemahaman kepada mahasiswa secara masif.

Bila mencermati rentang besaran uang kuliah kelompok mahasiswa UKT yang lebih rendah daripada mahasiswa non-UKT, berarti dengan adanya penerapan UKT secara kolektivitas sebenarnya meringkankan beban biaya kuliah mahasiswa, terutama bagi mahasiswa yang kemampuan ekonominya terbatas, karena uang kuliah yang ditanggung menjadi lebih rendah (UKT Kelompok 1). Hal yang demikian sesuai dengan pertimbangan dikeluarkannya Peraturan Menteri Pendidikan dan Kebudayaan Republik Indonesia (Permendikbud) Nomor 55 Tahun 2013, hal Menimbang huruf $b$ yang mengungkapkan "bahwa untuk meringankan beban mahasiswa terhadap pembiayaan pendidikan, perlu menetapkan uang kuliah tunggal di perguruan tinggi negeri di lingkungan Kementerian Pendidikan dan Kebudayaan". 
Dampak Biaya Kuliah Tunggal Terhadap Kualitas Layanan Pendidikan | Sumarno, dkk.

Penerimaan universitas tahun 2014 (sesudah penerapan UKT), yaitu sebesar Rp413.728.568.000,00 yang mengalami peningkatan sebesar $4,97 \%$ dari penerimaan tahun sebelumnya (sebelum penerapan UKT) sebesar Rp394.166.849.000. Hal itu didukung dari data proporsi penerimaan universitas yang bersumber dari masyarakat, yaitu meningkat 8,4\% menjadi 75,8\% pada tahun 2014 (sesudah penerapan UKT) dibanding pada tahun 2013 (sebelum penerapan UKT) yang hanya sebesar $67,4 \%$. Peningkatan tersebut juga didukung dari data tentang rata-rata UKT dan modusnya yang lebih besar dari rata-rata dan modus uang kuliah mahasiswa non-UKT. Peningkatan dana yang diperoleh universitas tersebut sesuai tujuan kebijakan UKT yaitu untuk meningkatkan pelayanan dengan cara membebankan biaya pendidikan kepada masyarakat secara proporsional sesuai kemampuannya.

Penggunaan dana universitas untuk biaya operasional (belanja barang di luar gaji/tunjangan) pada tahun 2014 (setelah penerapan UKT) justru mengalami penurunan sebesar $3,7 \%$ menjadi $48,7 \%$ dibanding tahun 2013 (sebelum penerapan UKT) sebesar 52,4\%. Penurunan alokasi untuk biaya operasional tersebut kemungkinan disebabkan adanya kelambatan dalam mengalokasikan biaya operasional ke unit-unit yang menjalankan layanan pendidikan secara langsung kepada mahasiswa. Mengingat biaya operasional sangat bersentuhan langsung dengan layanan pendidikan, maka penurunan ini dapat mengakibatkan penurunan layanan pendidikannya. Tetapi di lain pihak adanya peningkatan belanja bantuan sosial yang dapat untuk membantu masyarakat yang kurang mampu secara ekonomi untuk dapat mengenyam pendidikan tinggi. Untuk menjaga alokasi biaya operasional tidak menurun dapat dilakukan pengalokasian dana kepada unit-unit yang menjalankan layanan pendidikan kepada mahasiswa, secara cepat, tepat, dan akurat karena dana dari uang kuliah yang masuk sudah diketahui pada awal semester.
Dari sisi mutu pelayanan, hasil penelitian menunjukkan bahwa mutu layanan pendidikan yang dirasakan mahasiswa kelompok UKT lebih rendah dibanding menurut mahasiswa Non-UKT. Perbedaan yang lebih rendah setelah penerapan UKT tersebut secara statistik terbukti signifikan. Hal ini dapat dipahami karena mahasiswa kelompok UKT merasa bahwa layanan pendidikan yang diterimanya tidak sebanding dengan uang kuliah yang mereka bayarkan, karena uang kuliahnya lebih besar dibanding uang kuliah mahasiswan nonUKT. Hal itu juga didukung oleh jumlah mahasiswa yang membayar uang kuliah lebih tinggi dibanding mahasiswa non-UKT, yaitu dari rata-rata dan mode biaya pendidikan mahasiswa kelompok UKT yang lebih tinggi daripada mahasiswa kelompok non-UKT. Bila mencermati bahasan tentang alokasi dana untuk biaya operasional di atas, mutu layanan yang lebih rendah menurut mahasiswa kelompok UKT juga disebabkan oleh penurunan proporsi biaya operasional pada tahun 2014 (setelah peneerapan UKT). Proporsi biaya operasional pada tahun 2014 (setelah penerapan UKT) justru menurun, maka penilaian mutu layanan pendidikan menurut mahasiswa kelompok UKT menjadi lebih rendah dibanding penilaian mahasiswa non-UKT karena dengan menurunnya biaya operasional maka kegiatan yang berkenaan dengan layanan mahasiswa juga menurun. Hal ini misalnya terjadi pada ujian semester yang pada masa sebelum UKT mahasiswa langsung membayar biayanya ke fakultas dan langsung digunakan untuk membiayai kebutuhan pelaksanaan ujian oleh fakultas. Tetapi dengan adanya penerapan UKT, biaya tersebut harus diminta ke universitas sehingga menjadi terkendala seperti terlambat ataupun tidak sesuai yang dibutuhkan. Begitu juga untuk kegiatankegiatan operasional yang lain seperti tes TOEFL dan kegiatan kemahasiswaan.

Mutu layanan pendidikan yang dirasakan mahasiswa UKT ternyata lebih rendah dari mutu layanan pendidikan yang dirasakan mahasiswa non-UKT dan perbedaannya signifikan, sedangkan besaran uang kuliah yang 
Kelola: Jurnal Manajemen Pendidikan, Vol. 4, No. 2, Juli-Desember 2017

dikeluarkan mahasiswa UKT relatif sama dengan mahasiswa non-UKT. Hal itu berarti bahwa antara besaran UKT walaupun besaran uang kuliah mahasiswa yang dibayarkan tidak seiring dengan mutu layanan pendidikan yang diterima mahasiswa. Ini menunjukkan bahwa UKT tidak berpengaruh terhadap mutu layanan pendidikan universitas. Hal yang demikian sejalan dengan hasil penelitian Suhaylide (2013) yang mengungkapkan bahwa pengaruh biaya pendidikan terhadap kepuasan mahasiswa berada pada kategori sedang.

Pengelolaan UKT di Universitas Riau pada tahun 2014 masih menimbulkan persoalan sehingga menimbulkan dampak yang menghambat layanan pendidikan. Di samping dari segi pengalokasian biaya operasional yang menurun dari tahun sebelumnya, dari segi proporsi jumlah mahasiswa yang masuk dalam Kelompok UKT 1 masih berada di bawah 5\%. Hal ini memang dapat meningkatkan pendapatan dana universitas menjadi lebih besar, namun proporsi yang kurang dari 5\% belum sesuai dengan Permendikbud Nomor 73 Tahun 2014 Pasal 4 ayat (1) yang menyatakan bahwa uang kuliah tunggal kelompok 1 diterapkan paling sedikit 5 (lima) persen dari jumlah mahasiswa yang diterima di setiap perguruan tinggi negeri. Bila proporsi minimal dapat dipenuhi, sebenarnya memberikan manfaat bagi universitas yang berupa timbulnya atau meningkatnya citra baik universitas, sebagaimana diungkapkan Wijatno (2009) bahwa cost leadership strategy yang berupa harga jual yang lebih rendah merupakan salah satu strategi mengelola citra. Pemenuhan proporsi jumlah mahasiswa UKT kelompok 1 sebenarnya dapat dilakukan dengan mengalihkan sebagian mahasiswa UKT kelompok 2 (sebanyak 0,8\%) dan sebagian mahasiswa UKT kelompok 3 (sebanyak 2,3\%). Agar pengalihan sebagian jumlah mahasiswa tersebut tidak mengurangi dana yang diterima universitas, maka perlu juga mengalihkan sebagian mahasiswa UKT kelompok 3 ke UKT kelompok 4 atau UKT kelompok 4 ke UKT kelompok 5. Pengalihan sebagian mahasiswa ke UKT kelompok 3 atau 4 ke UKT kelompok yang lebih besar juga memungkinkan karena rentang maksimum besaran uang kuliah nonUKT (Rp 27.000.000,00) masih dapat dijangkau. Artinya mahasiswa yang memiliki kemampuan untuk membayar UKT kelompok 4 ataupun kelompok 5 masih ada potensinya.

\section{SIMPULAN DAN SARAN}

\section{Simpulan}

Besaran uang kuliah mahasiswa UKT secara relatif tidak berbeda dengan uang kuliah mahasiswa non-UKT. Mahasiswa UKT "merasa" uang kuliahnya lebih besar karena membayarnya sekaligus pada saat awal semester (masa pembayaran uang kuliah) sedangkan mahasiswa non-UKT membayar biaya kuliah secara berangsur sesuai jenis biayanya selama satu semester. Proporsi sumber dana yang berasal dari masyarakat yang berupa penerimaan negara bukan pajak (PNBP) meningkat setelah penerapan UKT. Tetapi proporsi alokasi dana untuk biaya operasional (belanja barang) justru menurun. Mahasiswa kelompok UKT menilai mutu layanan pendidikan lebih rendah dibanding mahasiswa kelompok non-UKT dan perbedaanya terbukti signifikan. Hal ini dapat terjadi karena mahasiswa UKT "merasa" membayar uang kuliah lebih besar daripada mahasiswa nonUKT atau karena alokasi dan untuk biaya operasional (belanja barang) menurun. Mutu layanan pendidikan tidak dipengaruhi oleh UKT, tetapi lebih dipengaruhi oleh alokasi dan yang diperuntukkan bagi biaya operasional pendidikan. Kebijakan UKT dapat membantu masyarakat yang memiliki kemampuan akademik tetapi ekonominya tidak/kurang mampu, untuk dapat mengenyam pendidikan tinggi. Bantuan tersebut tercermin pada Pengelompokan besarnya UKT yang didasarkan kemampuan ekonomi orangtua/ mahasiswa dari kelompok ekonomi tidak mampu (UKT kelompok 1) hingga kelompok ekonomi sangat mampu (UKT kelompok 5).

\section{Saran}

Bagi Universitas dan fakultas: a) perlu lebih memberdayakan sumberdaya manusia dosen untuk menggali dana-dana kerjasama 
Dampak Biaya Kuliah Tunggal Terhadap Kualitas Layanan Pendidikan | Sumarno, dkk.

untuk meningkatkan penerimaan, b) perlu meningkatkan program yang berkenaan dengan/berorientasi pada kepentingan pembelajaran mahasiswa baik program pendidikan, penelitian, maupun pengabdian kepada masyarakat, c) Pengalokasian dana, khususnya yang bersumber dari uang kuliah mahasiswa, diprioritaskan untuk program kegiatan yang bersentuhan langsung dengan layanan pendidikan bagi mahasiswa. Bagi pihak lain yang berkepentingan perlu dilakukan penelitian lebih lanjut tentang faktor yang mempengaruhi mutu layanan pendidikan, sehigga dapat digunakan sebagai bahan untuk menggerakan peningkatan mutu layanan pendidikan secara lebih efektif dan efisien.

\section{DAFTAR PUSTAKA}

Bahana Mahasiswa. 10 Juni, (2013). Uang Kuliah Tunggal UR Ada Yang Janggal, (Online), http://bahana mahasiswa.co/? $\mathrm{p}=699$.

Dedi Supriadi. (2006). Satuan Biaya Pendidikan Dasar dan Menengah. Bandung: Remaja Rosdakarya.

Elfindri. (2011). Pendidikan Sebagai Barang Ekonomi. Bandung: Lubuk Agung.

Gagasan Riau. (2013). Desak Batalkan UKT, Mahasiswa Unri Duduki Kantor Rektorat,http://gagasanriau.com/desakbatalkan-ukt-mahasiswa-unri-dudukikantor-rektorat/

Indrawan, R. 2008). Manajemen Kinerja dalam Meningkatkan Akuntabilitas Pengelolaan PTS. Makalah disampaikan pada Penataran Bagi Pengurus Yayasan, Pimpinan PTS dan Dosen di lingkungan PTS Kopertis Wilayah IV Jabar dan Banten, 22-23 Juli.

John, R. L. \& Morphet, E.L. (1997). The Economic and Financing of Education. New Jersey: Prentice Hall.

Kampus Okezone. (2013). UKT Tak Transparan, Ribuan Mahasiswa UNRI Demo Rektorat, http://kampus.okezone.com/read/2013/10/08/373/ 878576/ukt-tak-transparan-ribuanmahasiswa-unri-demo-rektorat.
Mulyasa. (2004). Manajemen Berbasis Sekolah: Konsep, Strategi, dan Implementasi. Bandung: Remaja Rosdakarya.

Michael, S. O. (2005). Financing Higher Education In A Global Market: A Contextual Background. Financing Higher Education In A Global Market. Editor: Steve O. Michael and Mark A. Kretovics. New York: Algora Publishing.

Peraturan Pemerintah Republik Indonesia Nomor 48 Tahun 2008 tentang Pendanaan Pendidikan.

Peraturan Pemerintah Republik Indonesia Nomor 17 Tahun 2010 tentang Pengelolaan dan Penyelenggaraan Pendidikan.

Permendikbud Nomor 55 Tahun 2013 tentang Biaya Kuliah Tunggal dan Uang Kuliah Tunggal Pada Perguruan Tinggi Negeri Di Lingkungan Kementerian Pendidikan dan Kebudayaan.

Pewarta Indonesia. (2013). Ribuan Mahasiswa Universitas Riau Pertanyakan Tranparansi Dana UKT, http://pewartaindonesia.com/berita/

pendidikan/12479-ribuan-mahasiswauniversitas-riau-pertanyakantranparansi-dana-ukt.html.

Ruben, B. D. (1999). Toward A Balanced Scorecard for Higher Education: Rethinking the College and University Excellence Indicator Framwork. Higher Education Forum 99-02 Fall, 1999. New Jersey: The Hunter Group in their Higher Education White Paper Series.

Schreiner, L. A. \& Juillerat, S. L. (2009). The Student Satisfaction Inventory, (http://www.ecsu.edu/academics/office s/iera/docs/SSIInterpretiveGuide200910.pdf),

Singgih, M. L. \& Rahmayanti. (2008). FaktorFaktor yang Mempengaruhi Kualitas Pendidikan Pada Perguruan Tinggi. Prosiding Seminar Nasional Teknoin 2008 Bidang Teknik Industri. Yogyakarta, 22 November 2008. 
Kelola: Jurnal Manajemen Pendidikan, Vol. 4, No. 2, Juli-Desember 2017

Suharsimi Arikunto, dan Lia Yuliana. (2009).

Manajemen Pendidikan. Yogyakarta:

Aditya Media.

Suhaylide, I. S. (2013). Pengaruh Mutu

Layanan Akademik dan Biaya

Pendidikan Terhadap Kepuasan

Mahasiswa Pada Sekolah Tinggi

Pariwisata Bandung. Masters thesis, http://repository.upi.edu/2812/.

Sumarno. (2012). Rendahnya Mutu Pendidikan

Tinggi di Indonesia: Penyebab dan

Strategi Peningkatannya. Jurnal

Pendidikan. 3(2) 75-83.

Sumarno, Kartikowati, S., \& Astuti, R. (2014).

Pembiayaan Pendidikan SMA

"Unggul" di Kota Pekanbaru dan

Pengaruhnya Terhadap Mutu Hasil

Belajar Siswa. http://repository.unri. ac.id/xmlui/handle/123456789/6378.

Tilaar, H.A.R. (2008). Manajemen Pendidikan

Nasional: Kajian Pendidikan Masa

Depan. Bandung: Rosdakarya.

Undang-Undang Republik Indonesia Nomor 12

Tahun 2012 tentang Pendidikan Tinggi.

Wissema, J.G. 2009. Towards the Third

Generation University: Managing the

University in Transition. Cheltenham:

Edward Elgar

Wijatno, S. (2009). Pengelolaan Perguruan

Tinggi Secara Efisien, Efektif, dan

Ekonomis: Untuk meningkatkan Mutu

Penyelenggaraan Pendidikan dan Mutu

Lulusan. Jakarta: Salemba Empat. 